\title{
A IMPORTÂNCIA DE OUTROS OLHARES VOLTADOS À CARTOGRAFIA NO ENSINO BÁSICO
}

Wagna Cristina Ferreira Moura, ${ }^{1}$ Universidade Federal de Campina Grande (UFCG), wcfm@ hotmail.com

Odinei Edson Leite Brasil, ${ }^{2}$ Universidade Federal de Campina Grande (UFCG) odinei1994@hotmail.com

Marcelo Henrique de Melo Brandão, Universidade Federal de Campina Grande (UFCG)

Palavras chaves: Tecnologia, educação, cartografia e oficinas.

\section{RESUMO:}

O presente trabalho buscar mostrar de forma sucinta, a necessidade da tecnologia como auxilio metodológico dentro da sala de aula, durante as aulas de geografia, as quais fossem voltadas para a temática de cartografia, viabilizando a utilização desses meios tecnológica, para a compreensão do conteúdo de forma prática, para que assim possamos unir a individualidade do aluno, no meio social que ele é inserido, fazendo isso através de aparelhos de GPS, celulares e computadores, realizando tais atividades em oficinas ministrada diretamente para o $1^{\circ}$ ano do ensino médio, ofertadas pelos graduando de geografia da UFCG - CFP, através de projetos, onde os mesmo sorteiam temas e elaboram temáticas que tiram o foco da aula ministrada de forma tradicional, e volta a uma realidade pós moderna, onde alguns autores utilizam da definição de uma Cibercultura, onde a tecnologia invade todos os espaços, e assim, o projeto tem a intenção de unir algo que mostra ser tão atrativo para os alunos, com o conteúdo ministrado em sala de aula, viabilizando um melhor aproveitamento de conhecimento e aprendizagem.

\section{INTRODUÇÃO}

O projeto cartografia e geotecnologias: Conhecimentos geoespacial na escola, da UNAGEO-UFCG, busca mesclar a tecnologia com a educação nas escolas, rompendo essa barreira de ensino apenas tradicional, voltado ao livro didático, sem tirar a importância do seu uso, mas abrindo uma nova oportunidade dos alunos estudarem a cartografia de uma maneira 
que abranja bem seus saberes, considerando que o nosso currículo educacional não abrange uma disciplina voltada apenas para os conhecimentos geoespaciais, e que os alunos só têm acesso a esses conhecimentos dentro da disciplina de geografia, é uma ótima oportunidade de aproximação desse conteúdo através da tecnologia, de maneira didática, atendendo a expectativas dos membros do projeto.

A tecnologia utilizada da maneira correta dentro de sala de aula, auxilia de maneira eficaz na educação, aproxima os alunos da sua realidade, mostrando que a cartografia está inserida de maneira ativa e direta no seu cotidiano, no trajeto de casa para a escola, no espaço do seu município, entre outros aspectos, e para isso podemos utilizar-se de tecnologias conhecidas pelos mesmos como celulares e computadores, e trazer novos aparelhos como os GPS de navegação.

\section{METODOLOGIA}

Em grupos sorteados dentro do projeto, ministramos as oficinas na escola técnica estadual da cidade de Cajazeiras - PB, Escola Cidadão Integrada, buscando sempre utilizar-se da maneira mais didática possível, para aproximar os alunos da cartografia, mostrando as mais variáveis maneiras de se adquirir o conhecimento geoespacial de maneira prática, buscando atender de maneira mais próxima possível o que diz o PCN de geografia na área de cartografia.

O nível de aprofundamento pretendido nos estudos, ou no ensino desses fenômenos que caracterizam os lugares, exigirá o trabalho com as diferentes escalas de representações cartográficas, com a linguagem gráfica por meio da produção e leitura de mapas. O nível de aprofundamento pretendido nos estudos, ou no ensino desses fenômenos que caracterizam os lugares, exigirá o trabalho com as diferentes escalas de representações cartográficas, com a linguagem gráfica por meio da produção e leitura de mapas.

Parâmetro Curricular Nacional - Geografia. Brasília 1998

\section{DESCRIÇÕES, RESULTADOS, INTERPRETAÇÕES}


As oficinas ajuda de maneira notável no entendimento da cartografia, aproximando os alunos da geografia, chamando sua atenção por meio da tecnologia, aumentando seu interesse nessa ciência que é tão importante nas nossas vidas, aproxima também de forma significativa a Universidade da escola, criando um laço que é de suma importância e dando a oportunidade dos graduandos interagir e se adaptar a escola antes mesmo do estagio, criando formas didáticas levando a tecnologia cada vez mais para o campo educacional, mostrando que os professores não precisa temer tal modernidade, mas que poderá adaptá-la para auxiliar na educação.

\section{CONSIDERAÇÕES FINAIS}

O projeto está em andamento, mas notam-se os interesses dos alunos e da escola, em questão de participação são bastante ativos, e já tiveram contato com a universidade e o grupo de pesquisa de Cartografia e do Laboratório de cartografia e geoprocessamento, e temos expectativas que esse projeto crie cada vez mais vínculos entre universidades $\mathrm{x}$ escola, levando tecnologia e conhecimento para dentro das salas de aulas da educação básica, mostrando aos professores e alunos o quanto a tecnologia é importante para agregar valores e saberes. Alguns autores têm chamado essa nova cultura de cibercultura - ou cultura digital (LEMOS, 2009; LÉVY, 2000); já reconhecendo que é uma cultura presente em sala de aula. Assim, devemos utilizar-se dos mais diferentes meios de conhecimentos, já que o mesmo nunca é demais.

\section{REFERENCIAS}

\section{PARÂMETRO CURRICULAR NACIONAL, GEOGRAFIA, MEC, BRASILIA 1998}

LEMOS, A. Cibercultura como território recombinante. In: TRIVINHO, E.; (. e CAZELOTO, E. A cibercultura e seu espelho: campo de conhecimento emergente e nova vivência humana na era da imersão interativa. São Paulo: ABCiber; Instituto Itaú Cultural. 2009. p. 38-46.

LÉVY, P. Cibercultura (2 ed.). (C. I. Costa, Trad.) São Paulo: Editora 34. 2000. 